\title{
Paradigma Strukturalisme Bahasa: Fonologi, Morfologi, Sintaksis, dan Semantik
}

\author{
Paradigm of Language Structuralism: Phonology, Morphology, Syntax, and Semantics \\ David Darwin'1, Miftahulkhairah Anwar ${ }^{2}$, Misbahul Munir ${ }^{3}$ \\ 1,2,3 Program Studi Pendidikan Bahasa, Fakultas Pascasarjana, Universitas Negeri Jakarta, Indonesia \\ e-mail: ${ }^{1}$ Daviddarwin8299@gmail.com, ${ }^{2}$ Miftahulkhairah@unj.ac.id, ${ }^{3}$ Munirmisbahul1868@gmail.com
}

\begin{abstract}
ABSTRAK
Tulisan ini didedikasikan untuk mengulas paradigma strukturalisme dalam bahasa manusia yang terdiri dari fonologi, morfologi, sintaksis dan semantik. Bahasa sebagai sebuah alat komunikasi yang tidak lepas dari nilai dan bentuk akan menjadi sebuah studi yang panjang bila ditelaah dari strukturnya. Pijakan dasar yang coba peneliti tawarkan di sini adalah paradigma strukturalisme yang dipopulerkan oleh Ferdinand de Saussure. Di mana dalam pandangannya ia menjabarkan bahwa sistem bahasa sebagai forma dan bukan substansi dapat disederhanakan dan dijelaskan sebagai relasi sintagmatis dan paradigmatis; dan sistem itu terjadi dari tingkat-tingkat struktur. Di antara struktur bahasa yang sudah menjadi bidang studi tersendiri yang begitu luas yakni; fonologi, morfologi, sintaksis dan semantik. Metode yang digunakan dalam penelitian ini adalah kualitatif dengan pendekatan kajian pustaka.
\end{abstract}

Kata kunci: fonologi, morfologi, sintaksis, semantik

\begin{abstract}
This paper is dedicated to reviewing the paradigm of structuralism in human language which consists of phonology, morphology, syntax and semantics. Language as a means of communication that cannot be separated from values and forms will be a long study when examined from its structure. The basic foundation that the researcher is trying to offer here is the structuralism paradigm popularized by Ferdinand de Saussure. Where in his view he explained that the language system as form and not substance can be simplified and explained as syntagmatic and paradigmatic relations; and the system occurs from the levels of the structure. Among the language structures that have become such a wide separate field of study, namely; phonology, morphology, syntax and semantics.The method used in this research is qualitative with a literature review approach.
\end{abstract}

Keywords: phonolgy, morphology, syntax, semantics

\section{PENDAHULUAN}

Manusia dalam kehidupannya tak bisa lepas dari bahasa. Bahasa menjadi sebuah sistem komunikasi verbal untuk menyuarakan ide, pikiran, hasrat dan keinginan dari satu manusia kepada manusia lainnya. Bentuk bahasa itu sendiri secara garis besar terbagi menjadi dua, bahasa lisan dan bahasa tulisan. Saking urgennya bahasa sebagai alat komunikasi utama membuat para pakar linguistik menyebut aktivitas berbahasa menjadi kebutuhan yang sama vitalnya dengan bernafas. Tak hanya manusia, sistem bahasa juga dipakai oleh seluruh makhluk hidup dengan berbagai bentuk dan jenisnya yang sangat beragam. Secara paradigmatik bahasa menjadi media yang fungsional tak sekadar sebagai sarana komunikasi, juga sebagai sarana aktualisasi diri dan bahkan ruang meditasi spiritual.

Banyak ahli bahasa mendedahkan beragam fungsi bahasa yang dipakai sesuai dengan keperluan manusia. Empat fungsi bahasa yang paling fungsional, yakni: bahasa sebagai alat untuk mengekspresikan diri, sebagai alat untuk berkomunikasi, sebagai alat untuk mengadakan integrasi dan beradaptasi sosial dalam lingkungan atau situasi tertentu, dan sebagai alat untuk melakukan kontrol sosial[1]. Fungsi bahasa, yakni: referensial (pesan yang disampaikan dalam suatu konteks/situasi tertentu), emotif (suasana batin penutur), puitis (fungsi estetis bahasa), fatis (untuk 
Jurnal SEMANTIKA, Volume 2, No. 02, Februari 2021, pp. 28-40

mempertahankan komunikasi), konatif (guna menimbulkan reaksi pada petutur) dan metalingual (untuk menjelaskan hal-hal yang terkait dengan bahasa itu sendiri agar menjadi lebih jelas)[2].

Ditinjau dari paradigma fungsionalnya, bahasa terdiri dari fungsi struktural dan fungsi pragmatis. Keduanya bersinggungan satu sama lainnya tatkala dipakai dalam interaksi sosial dalam kehidupan sehari-hari. Fungsi struktural menunjukkan bahasa terdiri dari unsur-unsur yang kemudian menjadi susunan sistem bahasa, seperti unsur fonologis, morfologis, gramatikal, sintaksis dan semantis. Sayangnya dewasa ini pemahaman bahasa yang struktural sangat jarang dipahami oleh setiap orang. Bahkan para mahasiswa jurusan bahasa pun masih terbata-bata, cenderung kaku bahkan ada yang kesulitan untuk memahami berbagai cabang keilmuan linguistik yang memang sangat luas. Untuk itu penulis akan mendedahkan tinjauan paradigma di sini, dengan cukup praktis dan terukur. Sehingga akan dipahami unsur-unsur pembentuk bahasa ataupun aspek-aspek strutural yang kemudian menjadi cabang keilmuan tersendiri dalam kajian linguistik.

Kenapa pemahaman tentang struktur bahasa perlu dipelajari lebih detail. Hal ini berkaitan erat dengan fenomena perkembangan bahasa verbal yang terus berjalan dari satu generasi ke generasi selanjutnya. Besar kemungkinan apabila pemahaman terhadap struktur linguistik tidak ditanamkan secara komprehensif, generasi kemudian akan kehilangan pemahaman substantif dalam mengenali identitas pembentuk bahasa ibunya. Bagaimanapun, bahasa selalu berkembang, variasi bahasa yang digunakan oleh masyarakat penuturnya sangat beragam. Semisal, di Indonesia saja memiliki 718 bahasa ibu yang sudah teridentifikasi, dan masih banyak yang belum, sedangkan dialeknya ada ribuan tentunya[3]. Aneka ragam bahasa itu terbentuk oleh setting kehidupan penuturnya; latar belakang sosial-kebudayaan masyarakat, letak geografi, pendidikan, usia, dan sebagainya. Banyak faktor yang menjadi sebab kemunculan dialek-dialek baru dalam bahasa. Bahkan dialek dalam suatu daerah akan terus berubah dari masa ke masa. Para sosiolinguis menetapkan bahasa selalu bersifat heterogen, dan variasi bahasa selalu berkembang dan berubah sebagai akibat keberagaman setting sosial budaya penuturnya dari satu masa ke masa selanjutnya[4].

Struktur bahasa dapat dibagi kedalam tiga tingkatan; bunyi pada dasarnya menduduki tingkat pertama, tata bahasa berada di tingkat kedua, sedangkan komponen makna menduduki tingkatan paling akhir. Korelasi antar struktur atau komponen bahasa itu prosesnya memiliki alur: (1) Bahasa pada mulanya berupa bunyi-bunyi abstrak yang mengacu adanya lambang atau simbol tertentu; (2) Sekumpulan lambang atau simbol merupakan seperangkat sistem yang memiliki tatanan ataupun kaidah tertentu; (3) Sekumpulan lambang atau simbol yang membentuk komponen tata bahasa dan memiliki bentuk dan kaidah itu mengasosiasikan suatu makna tersendiri. Pengkajian lebih detail terkait tahapan mulai dasar hingga akhirnya suatu struktur bahasa menjadi bidang kajian ilmu linguistik; fonologi, morfologi, sintaksis dan semantik[5].

Semisal dari aspek fonologis, sejak awal abad 19 para pakar bahasa menunjukkan unsur pembeda dalam struktur bahasa bisa dilihat dari fonem. Dalam bahasa Indonesia fonem $/ \mathrm{m} /$ membedakan makna kata 'makan' dengan 'akan'. Begitupun fonem dalam bahasa lainnya seperti fonem /p/ dan /f/ dalam bahasa Inggris memiliki makna berlainan. Demikian pula fonem /s/ dan /ts/ dalam bahasa Arab, meskipun beririsan tetapi membentuk arti yang lain. Contoh lainnya, tinjauan seputar morfem yang merupakan pembentuk kata yang memiliki makna baik gramatikal maupun leksikal. Begitupun pemahaman ihwal sintaksis, merupakan cabang linguistik yang penting dipahami[6]

Cabang-cabang keilmuan linguistik fonologis, morfologis, sintaksis, dan semantik dalam versi linguistik Arab juga memiliki istilah-istilah tersendiri. Fonologi dalam bahasa Arab disebut Ilmu al-Ashwat merupakan cabang linguistik yang mengelaborasi tentang lambang bunyi bahasa berdasarkan fungsinya. Morfologi disebut dengan Ilmu Shorof adalah ilmu yang mengkaji tentang jenis-jenis dan proses pembentukan kata dalam suatu bahasa. Sintaksis yang juga disebut dengan Ilmu Nahwu membahas tentang struktur kalimat, atau kaidah-kaidah yang mengatur suatu kalimat dalam suatu bahasa. Sedangkan semantik dalam linguistik Arab juga disebut Ilmu Dalalah yakni ilmu yang mengkaji makna, merupakan ilmu paling tua karena telah dibahas sejak zaman Aristoteles[7]. 


\section{METODOLOGI PENELITIAN}

Penelitian ini menggunakan metode deskriptif. Sebagaimana dijabarkan Suryabrata, metode deskriptif adalah sebentuk penelitian yang bertujuan untuk mengelaborasi ataupun menjelaskan secara komprehensif seluk-beluk seputar situasi dan kejadian[8]. Dalam penelitian ini, penulis menggunakan penelitian deskriptif kritis dengan lebih menekankan pada kekuatan analisis sumber-sumber dan data-data yang ada dengan mengandalkan teori-teori dan konsepkonsep yang ada untuk diinterpretasikan berdasarkan tulisan-tulisan yang mengarah kepada pembahasan struktural.

Penelitian ini menggunakan pendekatan kualitatif yakni suatu penelitian yang menggunakan kumpulan berbagai bahan-bahan praktis seperti studi kasus, pengalaman personal, wawancara dan lain-lain yang menjelaskan masalah-masalah yang dihadapi oleh individu dalam kehidupan sehari-hari[9][10]. Penelitian ini dijalankan berdasarkan paradigma strukturalisme. Paradigma di sini adalah acuan keyakinan dasar peneliti dalam melakukan penelitian yang melatari cara pandang melihat masalah, mencari penjelasan teoritis, mendesain penelitian hingga memberikan jawaban atas masalah yang diteliti. Pemilihan paradigma tentunya menyimpan nilai kepentingan tersendiri yang dibawanya[11].

Paradigma yang dipakai di sini adalah paradigma strukturalisme yang dipopulerkan oleh Ferdinand de Saussure. Saussure menjabarkan bahwa seluruh sistem bahasa sebagai forma dan bukan substansi sehingga dapat disederhanakan dan dijelaskan serta tersusun dari tingkat-tingkat struktur[6]. Pada tiap tingkat terdapat unsur-unsur yang saling berkontras dan berkombinasi dalam membentuk satuan-satuan yang lebih tinggi. Konsep struktural Saussure menggunakan mazhab diadik serta konsep strukturalnya menjadi empat; yakni: Penanda-Petanda, LangueParole, Sinkronik-Diakronik, Sintagmatik-Paradigmatik[12].

Studi ini didasarkan pada riset kepustakaan (library research). Di mana, library research adalah serangkaian studi yang berkaitan dengan metode pengumpulan data pustaka, membaca dan mencatat serta mengolah bahan penelitiannya. Ia merupakan suatu penelitian yang memanfaatkan sumber perpustakaan untuk memperoleh data penelitiannya secara komprehensif[13].

\section{HASIL DAN PEMBAHASAN}

\section{Fonologi}

Dari tinjauan etimologis fonologi tersusun dari dua kata bahasa Yunani yakni phone (bunyi) dan logos (ilmu). Dari gabungan kata itu ditemukan makna fonologi adalah ilmu bunyi. Fonologi merupakan bagian dari ilmu bahasa yang mengkaji bunyi. Kamus Besar Bahasa Indonesia mendefinisikan fonologi sebagai salah satu bidang linguistik yang menyelidiki bunyibunyi bahasa menurut fungsinya[14]. Bunyi bahasa adalah bunyi yang dibentuk oleh tiga faktor, yaitu pernafasan (sebagai sumber tenaga), alat ucap (yang menimbulkan getaran), dan rongga pengubah getaran (pita suara). Objek kajian fonologi yang pertama adalah bunyi bahasa (fon) yang disebut tata bunyi (fonetik) dan yang kedua mengkaji fonem yang disebut tata fonem (fonemik). Dengan demikian dapat disimpulkan bahwa fonologi adalah cabang ilmu bahasa (linguistik) yang mengkaji bunyi-bunyi bahasa, proses terbentuknya dan perubahannya[15].

Kajian fonologi terbagi menjadi dua cabang: fonetik dan fonemik. Bunyi-bunyi yang tidak membedakan makna disebut dengan fon dan dikenal dengan sebutan fonetik. Sedangkan bunyibunyi yang membedakan makna disebut dengan fonem atau fonemik. Tentunya dua cabang fonologi memiliki tujuan studi yang berbeda pula. Bagi seorang ahli fonetik, tujuan studinya adalah untuk menemukan kebenaran umum dan memformulasikan hukum-hukum tentang bunyibunyi dan pengucapannya, dan pengenalan produksi bunyi-bunyi ujar itu. Di samping itu, tujuan teoretis dari studi fonetik ini adalah untuk mendeskripsikan, mengklasifikasikan, dan menunjukkan fungsi hubungan yang satu dengan yang lain. Sedangkan bagi ahli fonemik (fisiologi) tujuan teoretis kajiannya adalah menemukan dan memformulasikan hukum-hukum 
bunyi bahasa tertentu, dan pengenalan akan fungsi-fungsi bunyi bahasa itu. Di samping itu, tujuan teoretis dari kajian fonemik ini adalah untuk mendeskripsikan, mengklasifikasikan, dan menunjukkan fungsi hubungan antara satu bunyi dengan bunyi yang lain.

Kajian fonetik menjadi cabang studi fonologi yang mempelajari bunyi bahasa tanpa memerhatikan apakah bunyi tersebut mempunyai fungsi sebagai pembeda makna atau tidak[16]. Fonetik ada tiga jenis, yakni: (1) Artikulatoris, yakni fonetik yang melihat bunyi bahasa dari segi cara menghasilkannya. (2) Akustis, yakni fonetik yang melihat bunyi dari segi maujudnya sebagai gelombang bunyi. (3) Auditoris, yakni fonetik yang melihat bunyi bahasa dari segi penangkapannya. Fonetik akustis dan auditoris tidak dikaji secara mendalam dalam ilmu bahasa, hanya fonetik artikulatoris yang dikaji dalam ilmu bahasa[17]. Di sini penulis akan menjabarkan klasifikasi yang menjadi medan bahasan fonetik yang meliputi struktur pembentuk bunyi secara komprehensif [18].

Tabel 1. Klasifikasi bunyi dalam kajian fonetik

\begin{tabular}{|c|c|c|c|c|}
\hline 1 & $\begin{array}{l}\text { Berdasarkan ada tidaknya } \\
\text { rintangan terhadap arus } \\
\text { udara dalam saluran suara. } \\
\text { Terdiri dari vokal, konsonan, } \\
\text { dan bunyi semi-vokal. }\end{array}$ & $\begin{array}{l}\text { Vokal adalah bunyi } \\
\text { bahasa yang arus } \\
\text { udaranya tidak } \\
\text { mengalami } \\
\text { rintangan. Pada } \\
\text { pembentukan vokal } \\
\text { tidak ada artikulasi }\end{array}$ & 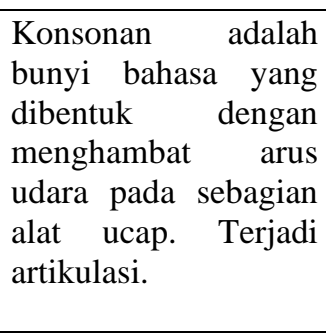 & $\begin{array}{l}\text { Bunyi semi-vokal } \\
\text { adalah bunyi yang } \\
\text { secara praktis } \\
\text { termasuk konsonan, } \\
\text { tetapi karena pada } \\
\text { waktu diartikulasika } \\
\text { belum membentuk } \\
\text { konsonan murni. }\end{array}$ \\
\hline 2 & $\begin{array}{l}\text { Berdasarkan jalan keluarnya } \\
\text { arus udara. Terbagi menjadi } \\
\text { bunyi nasal dan bunyi oral. }\end{array}$ & $\begin{array}{l}\text { Bunyi nasal, yaitu } \\
\text { bunyi yang } \\
\text { dihasilkan dengan } \\
\text { menutup arus udara } \\
\text { ke luar melalui } \\
\text { rongga } \\
\text { mulut dan } \\
\text { membuka jalan agar } \\
\text { arus udara dapat } \\
\text { keluar melalui } \\
\text { rongga hidung }\end{array}$ & $\begin{array}{lr}\text { Bunyi oral, yaitu } \\
\text { bunyi yang dihasilkan } \\
\text { dengan jalan } \\
\text { mengangkat ujung } \\
\text { anak tekak mendekati } \\
\text { langit-langit lunak } \\
\text { untuk menutupi } \\
\text { rongga hidung, } \\
\text { sehingga arus udara } \\
\text { keluar melalui mulut. }\end{array}$ & \\
\hline 3 & $\begin{array}{l}\text { Berdasarkan ada tidaknya } \\
\text { ketegangan arus udara saat } \\
\text { bunyi diartikulasikan. } \\
\text { Terbagi menjadi bunyi keras } \\
\text { (fortis) dan bunyi luna (lenis) }\end{array}$ & $\begin{array}{l}\text { Bunyi keras (fortis), } \\
\text { yaitu bunyi bahasa } \\
\text { yang pada waktu } \\
\text { diartikulasikan } \\
\text { disertai ketegangan } \\
\text { kuatarus. }\end{array}$ & $\begin{array}{l}\text { Bunyi lunak (lenis), } \\
\text { yaitu bunyi yang pada } \\
\text { waktu diartikulasikan } \\
\text { tidak disertai } \\
\text { ketegangan } \\
\text { kuatarus. }\end{array}$ & \\
\hline 4 & $\begin{array}{l}\text { Berdasarkan lamanya bunyi } \\
\text { pada waktu diucapkan atau } \\
\text { diartikulasikan. }\end{array}$ & Bunyi panjang & Bunyi pendek & \\
\hline 5 & $\begin{array}{l}\text { Berdasarkan } \\
\text { kenyaringannya }\end{array}$ & Bunyi nyaring & Bunyi pelan & \\
\hline 6 & $\begin{array}{l}\text { Berdasarkan perwujudannya } \\
\text { dalam suku kata }\end{array}$ & $\begin{array}{l}\text { Bunyi tunggal, yaitu } \\
\text { bunyi yang berdiri } \\
\text { sendiri dalam satu } \\
\text { suku kata (semua } \\
\text { bunyi vokal atau } \\
\text { monoftong dan } \\
\text { konsonan). }\end{array}$ & $\begin{array}{l}\text { Bunyi rangkap, yaitu } \\
\text { dua bunyi atau lebih } \\
\text { yang terdapat dalam } \\
\text { satu suku kata. Bunyi } \\
\text { rangkap } \\
\text { terdiri dari } \\
\text { (1) Diftong (vocal } \\
\text { rangkap): [ai], [au] } \\
\text { dan [oi]. } \\
\text { (2) Klaster (gugus } \\
\text { konsonan): [pr], [kr], } \\
\text { [tr] dan [bl]. }\end{array}$ & \\
\hline
\end{tabular}


Jurnal SEMANTIKA, Volume 2, No. 02, Februari 2021, pp. 28-40

7 Berdasarkan arus udara $\quad$ Bunyi egresif, yaitu Bunyi ingresif, yaitu bunyi yang di bunyi yang di bentuk bentuk dengan cara dengan cara mengeluarkan arus menghisap udara ke udara dari dalam dalam paru-paru.

paru-paru

Sementara itu macam-macam bunyi dalam kajian fonetik, yakni: (1) Bunyi segmental, yaitu bunyi yang dapat dipenggal atas ruas, dapat dibagi-bagi. Bunyi segmental dihasilkan pernafasan, alat ucap dan pita suara. Bunyi Segmental ada empat macam: (a) Konsonan, yakni bunyi yang terhambat oleh alat ucap, (b) Vokal, yakni bunyi yang tidak terhambat oleh alat ucap, (c) Diftong, yakni dua vokal yang dibaca satu bunyi, misalnya: /ai/ dalam sungai, /au/ dalam /kau/, (d) Kluster, yakni dua konsonan yang dibaca satu bunyi. (2) Bunyi suprasegmental, yaitu bunyi yang tidak dapat dipenggal atas segmen-segmennya / tidak dapat dibagi-bagi. Bunyi suprasegmental ada tiga, yakni: (a) Intonasi: jeda, tempo, tekanan (pitch), nada, irama, (b) Ekspresi (mimik/gesture), (c) Kinesik (gerakan organ tubuh: mata, tangan, kaki, kepala, dan lainnya). Dalam bahasa tulis ditandai dengan “, ; . ! ?” atau tanda baca lainnya[20].

Fonemik adalah Ilmu yang mempelajari fonem. kajian bunyi bahasa sebagai pembeda makna. Fonemik juga dapat didefinisikan sebagai satuan bahasa terkecil yang bersifat fungsional, artinya satuan fonem memiliki fungsi untuk membedakan makna. Fonem juga dapat dibatasi sebagai unit bunyi yang bersifat distingtif atau unit bunyi yang signifikan. Contohnya bunyi $[\mathrm{r}]+$ $[\mathrm{u}]+[\mathrm{s}]+[\mathrm{u}]+[\mathrm{h}]$ dengan bunyi $[\mathrm{l}]+[\mathrm{u}]+[\mathrm{s}]+[\mathrm{u}]+[\mathrm{h}]$, jika dibandingkan perbedaannya hanya pada bunyi yang pertama, yaitu bunyi [r] dan bunyi[1]. Dengan demikian dapat disimpulkan bahwa kedua bunyi tersebut adalah fonem yang berbeda dalam bahasa Indonesia, yaitu fonem /1/ dan fonem $/ \mathrm{r} /$.

Ditinjau dari klasifikasinya, fonem terdiri atas fonem vokal, konsonan, dan semi vokal. Untuk menelaah bunyi-bunyi fonem setidaknya ada empat premis yakni: (1) Bunyi bahasa saling memengaruhi atau dipengaruhi lingkungannya; (2) Bunyi bahasa itu membentuk pola simetris; (3) Bunyi bahasa yang secara fonetis mirip, harus digolongkan ke dalam kelas fonem yang berbeda; (4) Bunyi bahasa yang bersifat komplementer harus dimasukkan ke dalam kelas fonem yang sama[19].

Table 2. fenom

\begin{tabular}{lll}
\hline \multicolumn{1}{c}{ Fonem } & \multicolumn{1}{c}{ Konsonan berkelompok } & Artikulasi bunyi \\
\hline Simpan & mp pada kata simpan & Bilabial : mb \& mp \\
\hline Ambil & mb pada kata ambil & Alveolar : nd \& nt \\
\hline Tendang & nd pada kata tendang & Veral : ngg \& $\mathbf{n g k}$ \\
\hline Untung & nt pada kata untung & \\
\hline Unggul & ngg pada kata unggul & Palatal : $\mathbf{n j} \& \mathbf{n t}$ \\
\hline Tengkuk & $\mathbf{n g k}$ pada kata tengkuk & \\
\hline Tunjang & $\mathbf{n j}$ pada kata tunjang & \\
\hline Ancam & $\mathbf{n c}$ pada kata ancam & \\
\hline
\end{tabular}

\section{Morfologi}

Ditinjau secara leksikal, morfologi disebut juga ilmu bahasa yang mempelajari seluk beluk kata. Kamus Besar Bahasa Indonesia mendefinisikan morfologi sebagai cabang linguistik serta ilmu yang mempelajari susunan bagian kata secara gramatikal dan kombinasinya[20]. Pemahaman serupa juga disampaikan [21] yang menjabarkan bahwa morfologi dapat dianalisa kedalam dua bagian, yakni pertama, bidang linguistik yang mempelajari morfem dan kombinasikombinasinya; Kedua, bagian dari struktur bahasa yang mencakup kata dan bagian-bagian kata, atau disebut morfem[21]. Berdasarkan paparan tersebut dapat ditarik kesimpulan bahwa 
morfologi adalah sebuah ilmu yang termasuk dalam bidang kajian linguistik yang secara spesifik membahas susunan-susunan atau bagian-bagian kata (morfem) serta membahas variasi serta kombinasinya.

Perlu ditegaskan pula bahwa morfem adalah bentuk bahasa paling dasar atau kecil, sehingga tidak bisa lagi dibagi menjadi bagian-bagian yang lebih kecil. Misalnya 'tegak' ia merupakan morfem karena tidak bisa lagi diperkecil atau dipotong atau dibagi menjadi bagian lebih kecil. Seumpama 'tegak' dibagi menjadi 'te' dan 'gak' atau 'teg' dan 'ak', pembagian itu tidak bisa disebut morfem karena ketiadaan makna, baik makna leksikal maupun gramatikalnya. Morfem merupakan kata paling minimal yang bebas, artinya bentuknya bisa berdiri sendiri, bisa dikatakan, serta memiliki makna. Singkat kata, Badudu menyebut morfem merupakan satuan bahasa yang paling kecil sehingga tidak bisa dibagi lagi, serta memiliki makna baik leksikal maupun gramatikal[22].

Proses morfologi menurut [23] adalah cara pembentukan kata-kata dengan menghubungkan morfem yang satu dengan morfem lainnya. Proses morfologi meliputi (1) afiksasi, (2) reduplikasi, (3) perubahan intern, (4) suplisi, dan (5) modifikasi kosong. Uniknya, dalam bahasa Indonesia tidak ditemukan data proses morfologi yang berupa perubahan intern, suplisi, dan modifikasi kosong. Sehingga, proses morfologis dalam bahasa Indonesia cukup sederhana hanya melalui afiksasi dan reduplikasi. Di sini penulis hanya akan membahas kedua proses morfologi yang digunakan dalam bahasa Indonesia, yakni afiksasi dan reduplikasi[23]. Afiksasi adalah penggabungan akar kata atau pokok dengan afiks. Afiks terdiri dari tiga bentuk, yakni awalan (letaknya berada di depan bentuk dasar atau disebut juga prefiks), sisipan (letaknya di dalam kata atau disebut juga infiks) dan akhiran (letaknya selalu di akhir kata dan disebut juga sufiks). Selanjutnya terdapat pula konfiks yakni gabungan afiks yang berupa prefiks (awalan) dan sufiks (akhiran) yang merupakan satu-kesatuan afiks yang tidak terpisah. Artinya afiks gabungan hadir bersamaan sebagai morfem dasar serta membentuk suatu makna gramatikal pada bentukannya. Untuk lebih jelasnya bisa dilihat tabel 3

Tabel 3. Gramatikal suatu Bahasa

\begin{tabular}{|c|c|c|c|c|}
\hline \multicolumn{5}{|c|}{ 1. PREFIKS (AWALAN) } \\
\hline $\begin{array}{l}\text { Prefiks be(R)- } \\
\text { memiliki } \\
\text { beberapa variasi } \\
\text { bisa berubah } \\
\text { menjadi ber-, } \\
\text { be-dan bel-. }\end{array}$ & $\begin{array}{lr}\text { Prefiks } & \text { me }(N)- \\
\text { memiliki beberapa } \\
\text { variasi } & \text { bisa } \\
\text { berubah } & \text { mem-, } \\
\text { men-, } & \text { meny-, } \\
\text { meng-, } & \text { menge- } \\
\text { dan } m e- & \\
\end{array}$ & $\begin{array}{l}\text { Prefiks pe(R)- } \\
\text { adalah nominalisasi } \\
\text { dari prefiks be }(R)-\text { - } \\
\text { Variasinya pun } \\
\text { sama. Pe(R)- bisa } \\
\text { berubah menjadi pe- } \\
\text { dan pel-. }\end{array}$ & $\begin{array}{l}\text { Prefiks pe }(N)-\text { sejajar } \\
\text { dengan } \quad \text { prefiks } \\
m e(N)-. \quad P e(N)- \\
\text { memiliki variasi pem- } \\
\text {, pen-, peny-, peng-, } \\
\text { pe-, dan penge-. }\end{array}$ & $\begin{array}{l}\text { Prefiks te }(R)- \\
\text { memiliki } \\
\text { beberapa variasi, } \\
\text { yakni ter-dan tel- } \\
\text {. }\end{array}$ \\
\hline $\begin{array}{l}\mathrm{Be}(R)+\text { jalan } \rightarrow \\
\text { berjalan }\end{array}$ & $\begin{array}{l}M e(N) \text { - berubah } \\
\text { menjadi mem- } \\
\text { jika bergabung } \\
\text { dengan kata yang } \\
\text { diawali huruf /b/, } \\
\text { /f/, /p/, dan /v/. } \\
\text { Contohnya: } \\
M e(N) \text { - + pukau } \\
\rightarrow \text { memukau } \\
M e(N) \text { - + } \\
\text { bonceng } \rightarrow \\
\text { membonceng }\end{array}$ & $\begin{array}{l}\text { Pe(R)- bisa berubah } \\
\text { menjadi pe- jika } \\
\text { bergabung dengan } \\
\text { kata yang diawali } \\
\text { huruf /r/ dan kata } \\
\text { yang suku katanya } \\
\text { berakhiran er. } \\
\text { Contohnya: } \\
P e(R)-+ \text { rumus } \rightarrow \\
\text { perumus }\end{array}$ & $\begin{array}{lr}P e(N)- & \text { berubah } \\
\text { menjadi pen- jika } \\
\text { bergabung dengan } \\
\text { kata yang diawali oleh } \\
\text { huruf /t/, /d/, /c/, dan } \\
\text { /j/. Contohnya: } \\
\text { - Pencari } \\
\text { - Pendorong } \\
\text { - Penolong } \\
\text { - Penjinak }\end{array}$ & $\begin{array}{l}T e(R) \text { - berubah } \\
\text { menjadi ter- jika } \\
\text { bergabung } \\
\text { dengan kata yang } \\
\text { diawali oleh } \\
\text { huruf apa saja } \\
\text { kecuali kata anjur. } \\
\text { Contohnya: } \\
\text { - } \quad \text { Ternoda } \\
-\quad \text { Tertawa } \\
-\quad \text { Terbaca } \\
-\quad \text { Terguncang } \\
-\quad \text { Telanjur } \\
\end{array}$ \\
\hline $\begin{array}{l}B e(R)+\text { kerja } \\
\rightarrow \text { bekerja }\end{array}$ & $\begin{array}{l}M e(N) \text { - berubah } \\
\text { menjadi men- jika } \\
\text { bergabung dengan } \\
\text { kata yang diawali } \\
\text { oleh huruf /d/, /t/, }\end{array}$ & $\begin{array}{l}P e(R)-\quad \text { berubah } \\
\text { menjadi pel- jika } \\
\text { bergabung dengan } \\
\text { kata ajar. }\end{array}$ & $\begin{array}{lr}P e(N)- & \text { berubah } \\
\text { menjadi pem- jika } \\
\text { bergabung dengan } \\
\text { kata yang diawali oleh }\end{array}$ & $\begin{array}{l}T e(R)-\text { berubah } \\
\text { menjadi tel- jika } \\
\text { bergabung } \\
\text { dengan kata anjur. }\end{array}$ \\
\hline
\end{tabular}


Jurnal SEMANTIKA, Volume 2, No. 02, Februari 2021, pp. 28-40

\begin{tabular}{|c|c|c|c|}
\hline & $\begin{array}{l}\mathrm{j} /, \text { dan } / \mathrm{c} / . \\
\text { Contohnya: } \\
M e(N)+\text { jiplak } \rightarrow \\
\text { menjiplak } \\
M e(N)+\text { cari } \rightarrow \\
\text { mencari }\end{array}$ & $\begin{array}{l}P e(R)-\quad+\text { ajar } \rightarrow \\
\text { pelajar }\end{array}$ & 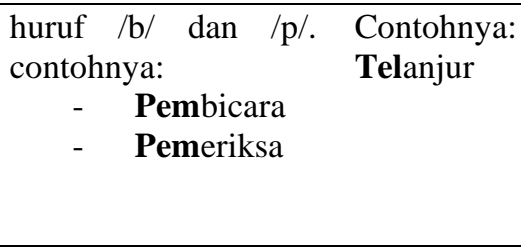 \\
\hline \multirow[t]{4}{*}{$\begin{array}{l}\mathrm{Be}(R)+\text { ajar } \rightarrow \\
\text { belajar }\end{array}$} & $\begin{array}{l}M e(N) \text { - berubah } \\
\text { menjadi meny- } \\
\text { jika bergabung } \\
\text { dengan kata yang } \\
\text { diawali oleh huruf } \\
\text { /s/. Contohnya: } \\
M e(N)-+ \text { sesal } \rightarrow \\
\text { menyesal }\end{array}$ & & $\begin{array}{l}P e(N)-\text { berubah } \\
\text { menjadi peny- jika } \\
\text { bergabung dengan } \\
\text { kata yang diawali oleh } \\
\text { huruf /s/. Contohnya: } \\
P e(N)-\quad+\quad \text { sisir } \\
\rightarrow \text { Penyisir }\end{array}$ \\
\hline & $\begin{array}{l}M e(N) \text { - berubah } \\
\text { menjadi meng- } \\
\text { jika bergabung } \\
\text { dengan kata yang } \\
\text { diawali dengan } \\
\text { huruf } / \mathrm{k} / \text { dan } / \mathrm{g} / \text {. } \\
\text { Contohnya: } \\
M e(N) \text { - + kuras } \rightarrow \\
\text { menguras } \\
M e(N) \text { - + garuk } \\
\rightarrow \text { menggaruk }\end{array}$ & & $\begin{array}{l}P e(N)-\quad \text { berubah } \\
\text { menjadi peng- jika } \\
\text { bergabung dengan } \\
\text { kata yang diawali oleh } \\
\text { huruf /g/ dan /k/. } \\
\text { Contohnya: } \\
\quad \text { Penggerak } \\
\text { - Pengait }\end{array}$ \\
\hline & $\begin{array}{l}M e(N) \text { - berubah } \\
\text { menjadi menge- } \\
\text { jika bergabung } \\
\text { dengan kata yang } \\
\text { terdiri dari satu } \\
\text { suku kata. } \\
\text { Contohnya: } \\
M e(N) \text { - las } \rightarrow \\
\text { mengelas }\end{array}$ & & $\begin{array}{l}P e(N)-\text { berubah } \\
\text { menjadi penge- jika } \\
\text { bergabung dengan } \\
\text { kata yang terdiri atas } \\
\text { satu suku kata. } \\
\text { Contohnya: } \\
P e(N) \text { - + Cor } \rightarrow \\
\text { Pengecor. }\end{array}$ \\
\hline & & & $\begin{array}{l}P e(N)-\quad \text { berubah } \\
\text { menjadi pe- jika } \\
\text { bergabung dengan } \\
\text { kata yang diawali oleh } \\
\text { huruf /m/, /l/, dan /r/. } \\
\text { Contohnya: } \\
\text { - Pemurung } \\
\text { - Pelawak } \\
\text { - Perancang }\end{array}$ \\
\hline
\end{tabular}

\section{INFIKS (SISIPAN)}

Infiks -el-, misalnya: geletar Infiks -er-, misalnya: Infiks -em-, misalnya: gemuruh, gerigi, seruling gemetar

\section{SUFIKS (AKHIRAN)}

Sufiks -an. Contohnya: luapan, Sufiks

-i. Sufiks

-kan. Sufiks -nya. mainan, cobaan

Contohnya: penuhi, patuhi, gemari
Contohnya: ucapkan, Contohnya:

keluhkan, abaikan berdirinya, ucapnya, ketuknya 
Jurnal SEMANTIKA, Volume 2, No. 02, Februari 2021, pp. 28-40

\begin{tabular}{|c|c|c|c|c|}
\hline \multirow[b]{2}{*}{$\begin{array}{l}\text { Konfiks pe(R)-an. } \\
\text { perdamaian, } \\
\text { perubahan }\end{array}$} & \multicolumn{4}{|c|}{ 4. KONFIKS (GABUNGAN PREFIKS + SUFIKS) } \\
\hline & $\begin{array}{r}\text { Contohnya: } \\
\text { persekutuan, }\end{array}$ & $\begin{array}{l}\text { Konfiks pe(N)-an. } \\
\text { Contohnya: } \\
\text { pendalaman, } \\
\text { pendudukan, } \\
\text { pendakian }\end{array}$ & $\begin{array}{l}\text { Konfiks ke-an. } \\
\text { Contohnya: } \\
\text { ketuhanan, } \\
\text { kelebihan, keputusan }\end{array}$ & $\begin{array}{l}\text { Konfiks be }(\mathrm{R}) \text {-an } \\
\text { Contohnya: } \\
\text { berlawanan, } \\
\text { bertabrakan, } \\
\text { berlumuran }\end{array}$ \\
\hline
\end{tabular}

Reduplikasi merupakan proses pengulangan kata dasar, apakah itu secara keseluruhan ataupun sebagian. Dalam bahasa Indonesia reduplikasi terbagi menjadi empat bagian. (1) Reduplikasi seluruh, yakni pengulangan bentuk dasar kata tanpa adanya perubahan fonem dan tanpa adanya proses afiks. (2) Reduplikasi sebagian, yakni pengulangan sebagian morfem dasar, apakah pada bagian awal maupun akhirnya. (3) Reduplikasi perubahan fonem, yakni pengulangan bentuk dasar kata dengan adanya perubahan fonem. Dan (4) reduplikasi berimbuhan, yakni pengulangan bentuk dasar yang diulang secara keseluruhan dan mengalami proses pembubuhan afiks, baik itu prefiks, infiks, sufiks maupun konfiks. Untuk lebih jelasnya bisa dilihat tabel 4.

Table 4. Reduplikasi

\begin{tabular}{lllll}
\hline & \multicolumn{3}{c}{ REDUPLIKASI } \\
\hline Contoh pengulangan & Contoh pengulangan & Contoh pengulangan & Contoh pengulangan \\
seluruh: & sebagian: & dengan & perubahan \\
Kata $\rightarrow$ kata-kata & Tapi $\rightarrow$ tetapi & fonem: & & Batu $\rightarrow$ batu-batuan \\
Hati $\rightarrow$ hati-hati & Suka $\rightarrow$ sesuka & Warna $\rightarrow$ warna- & Ugal $\rightarrow$ ugal-ugalan \\
Pura $\rightarrow$ pura-pura & Berapa $\rightarrow$ beberapa & warni & Tolong $\rightarrow$ tolong- \\
& & Tunggang & menolong \\
& & tunggang-langgang & Merah $\rightarrow$ kemerah- \\
& & Asal $\rightarrow$ asal-usul & merahan \\
& & & \\
& & &
\end{tabular}

Akar kata sintaksis berasal dari bahasa Yunani Kata sintaksis berasal dari gabungan dua kata dari bahasa Yunani, 'sun' (arti: dengan) dan kata 'tattein' (arti: menempatkan). Sehinga secara etimologis didapatkan makna menempatkan sekelompok kata atau kalimat. Sintaksis sebagai cabang linguistik sudah dirumuskan sejak zaman para ahli linguistik Yunani-Latin sampai sekarang, tentunya sintaksis mengalami perkembangan sebagaimana bahasa itu berkembang. Kamus Besar Bahasa Indonesia mendefinisikan sintaksis dalam tiga bentuk; (1) pengaturan dan hubungan kata dengan kata lain atau dengan satuan lain yang lebih besar, (2) sebagai cabang linguistik tentang susunan kalimat dan bagiannya, atau disebut pula ilmu tata kalimat, (3) subsistem bahasa yang mencakup hal tersebut[24][25].

Menurut [6] sintaksis adalah cabang linguistik yang memelajari pengaturan dan hubungan antara kata dan kata, atau antara kata dan satuan-satuan yang lebih besar, atau antarsatuan yang lebih besar itu di dalam bahasa. Lebih jelasnya, sintaksis membahas tentang kaidah atau tata bahasa bagaimana pengaturan dan hubungan kata-kata dalam membentuk frase, klausa, dan kalimat[6]. Demikian pula [26] mendefinisikan sintaksis sebagai cabang ilmu linguistik yang menyangkut susunan kata-kata di dalam kalimat. Sintaksis adalah ilmu yang mempelajari hubungan antara kata atau frase atau klausa atau kalimat yang satu dengan kata atau frase atau klausa atau kalimat lainnya[26].

Dalam kajian sintaksis terdapat komponen satuan bahasa yang digunakan untuk membangun konstruksi sintaksis, yakni: frasa, klausa, kalimat, wacana. Namun perlu didedahkan pula fungsi dan kategori sintaksis itu sendiri. Fungsi sintaksis berkaitan dengan istilah subjek, predikat, objek, dan keterangan. Kategori sintaksis berkaitan dengan istilah nomina, verba, adjektiva, pronomina atau disebut juga dengan kelas kata (part of speech). Pengkajian sintaksis terdiri dari satuan bahasa mulai dari yang terkecil berupa kata atau frasa hingga menjadi suatu wacana. Pertama, frasa adalah satuan gramatikal yang berupa gabungan kata dengan kata yang 
bersifat nonpredikatif atau tidak ada predikat di dalamnya. Kedua, klausa adalah satuan gramatikal yang berupa gabungan kata yang sekurang-kurangnya memiliki fungsi subjek dan predikat yang berpotensi menjadi kalimat. Namun klausa tidak memiliki intonasi akhir seperti: tanya, perintah, maupun berita. Ketiga, kalimat adalah satuan gramatikal yang terdiri dari rangkaian kata yang dapat berdiri sendiri dan memberikan makna yang lengkap. Atau bisa disebut satuan bahasa terkecil yang mengungkapkan suatu pokok pikiran. Keempat, wacana adalah rangkaian kalimat bahkan paragraf yang mengungkapkan ide atau gagasan pikiran yang utuh. Wacana merupakan satuan terbesar dari bahasa yang dapat mengungkapkan seluruh gagasan penulisnya[27].

Table 5. Satuan sintaksis

\begin{tabular}{|c|c|c|c|}
\hline \multicolumn{4}{|c|}{ SATUAN SINTAKSIS } \\
\hline Frasa & Klausa & Kalimat & Wacana \\
\hline $\begin{array}{l}\text { Contoh: Bermain } \\
\text { layang-layang }\end{array}$ & $\begin{array}{l}\text { Contoh: Adi bermain } \\
\text { layang-layang }\end{array}$ & $\begin{array}{lr}\text { Contoh: Setiap Minggu } \\
\text { pagi, Adi bermain } \\
\text { layang-layang } \\
\text { lapangan bola }\end{array}$ & 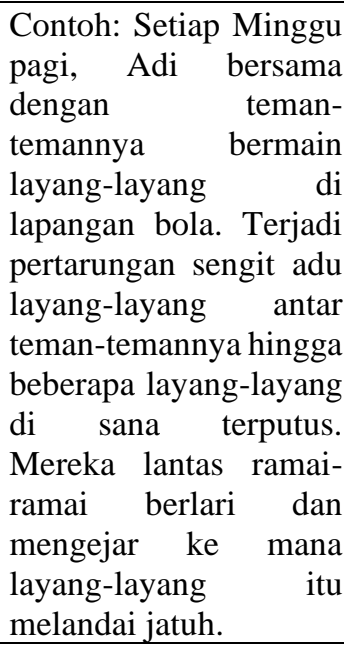 \\
\hline
\end{tabular}

Fungsi sintaksis berkaitan dengan struktur dalam tata bahasa satuan yang dibahas untuk mengidentifikasi fungsi tiap-tiap satuan kata dalam kontruksi tubuh sintaksis. Fungsi sintaksis ada lima: subjek (S), predikat (P), objek (O), keterangan (Ket) dan komplemen (Kom). Pertama, subjek yakni unsur yang mewakili seseorang yang melakukan suatu perbuatan atau aktivitas tertentu. Kedua, predikat adalah unsur yang dinyatakan sebagai perbuatan atau aktivitas yang dilakukan oleh subyek. Ketiga, objek adalah unsur yang dikenai perbuatan atau tindakan oleh subyek. Keempat, keterangan adalah unsur yang menjelaskan bagaimana, di mana, atau kapan peristiwa atau aktivitas tersebut terjadi. Kelima, komplemen atau pelengkap fungsinya serupa objek tetapi tidak bisa diubah menjadi subjek pada kalimat pasif[28]. Realisasinya dalam sebuah kalimat, kelima fungsi tersebut tidak selalu hadir bersama-sama. Terkadang sebuah kalimat hanya terdiri atas fungsi S dan P, S-P-O, S-P-Pel, S-P-K, S-P-O-K, atau S-P-Pel-K[7].

Kategori sintaksis merupakan jenis atau tipe kata atau frasa yang menjadi pengisi fungsifungsi sintaksis [29] kategori sintaksis di sini berkaitan dengan istilah nomina, verba, adjektiva, adverbia, numeralia, preposisi, konjungsi, dan pronomina. Pengisi fungsi tersebut dapat berupa frasa, sehingga selain kelas kata yang nomina, terdapat pula frasa nominal. Begitu juga dengan adjektiva, adverbia, numeralia, preposisi, konjungsi, dan pronomina yang dapat berupa frasa sebagai pengisi fungsi sintaksis. mpat kategori sintaksis yang utama, yaitu: (1) verba atau kata kerja, (2) nomina atau kata benda, (3) adjektiva atau kata sifat, dan (4) adverbia atau kata keterangan. Di samping kategori utama, terdapat juga kata tugas yang terdiri atas preposisi atau kata depan, konjungtor atau kata sambung, dan partikel[29]. Sebagaimana paparan Badudu, peran sintaksis terdiri dari pembagian kalimat atas jenis pelaku (agentif), penderita (objektif), penerima atau penyerta (benefaktif), tempat (lokatif), waktu (temporal), perbandingan (komparatif), alat (instrumental), penghubung (konjungtif), perangkai (preposisi), dan seruan (interjeksi)[7][30]. 
Jurnal SEMANTIKA, Volume 2, No. 02, Februari 2021, pp. 28-40

Table 6. Peran sintaksis

\begin{tabular}{lllll}
\hline \multicolumn{1}{c}{ Contoh } & \multicolumn{1}{c}{ Adi } & \multicolumn{1}{c}{ bermain } & layang-layang & \multicolumn{1}{c}{ di lapangan } \\
\hline Fungsi & Subjek & predikat & Objek & Keterangan \\
\hline Kategori & Nomina & verba & Pronomina & Adverbia \\
\hline Peran & Pelaku (agentif) & aktif & instrumental & lokatif \\
\hline
\end{tabular}

Ditinjau dari akar katanya, semantik berasal dari bahasa Yunani 'Semanein (berarti/bermaksud)', yang berarti to signify (memaknai). Semantik berarti ilmu arti kata atau bisa disebut ilmu yang membahas makna dalam bahasa. Sebagai sebuah istilah teknis, semantik juga disebut studi tentang makna serta pergeserannya. Makna semantik sebagai suatu studi tentang makna[31]. Berhubung makna lahir dan menjadi bagian dari bahasa, maka semantik otomatis menjadi bagian dari studi linguistic [5]. Kamus Besar Bahasa Indonesia mendefinisikan semantik dalam dua bentuknya; (1) ilmu tentang makna kata dan kalimat; pengetahuan mengenai selukbeluk dan pergeseran arti kata, (2) bagian struktur bahasa yang berhubungan dengan makna ungkapan atau struktur makna suatu wicara[5]. Banyaknya variasi makna atau bentuk semantik, meliputi: denotatif, konotatif, leksikal, gramatikal, kognitif dan masih banyak lainnya [5]. Beberapa macam makna atau arti dalam kajian semantik, tapi yang paling siginifikan dikaji adalah makna leksikal dan gramatikal[32]. Pertama, makna leksikal yaitu arti yang terkandung kata-kata sebuah bahasa yang bersifat tetap, seperti digambarkan dalam sebuah kamus. Contohnya: kata 'mobil' makna leksikalnya adalah kendaraan darat yang digerakkan oleh tenaga mesin, beroda empat atau lebih (selalu genap)[33]. Leksikal adalah bentuk adjektif yang diturunkan dari bentuk nomina 'leksikon' (vokabuler, kosa kata, perbendaharaan kata)[1]. Satuan dari leksikon adalah 'leksem', yaitu satuan bentuk bahasa yang bermakna, atau makna harfiah[29]. Sedangkan makna gramatikal, yakni arti yang timbul karena relasi satuan gramatikal baik dalam konstruksi morfologi, frase, klausa atau kalimat. Semisal kata 'bermobil' memiliki awalan ber- dan mobil, maknanya mengendarai sebuah mobil[29].

Pemaknaan referensial maupun non-referensial cuma dibedakan pada ada tidaknya referens atau acuannya. Sebuah kata atau leksem dikatakan bermakna referensial jika ada referensnya atau acuannya. Contohnya 'mobil' dan 'motor' adalah kata yang bermakna referensial karena memiliki referens, yakni sejenis kendaraaan bermotor. Sebaliknya non-referensial berarti sejumlah kata yang tidak memiliki referen. Contohnya: 'dan', 'sedangkan', 'karena' adalah sejumlah kata yang tidak memiliki makna referens. Semantik denotatif adalah makna asli, makna asal atau makna sebenarnya yang dimiliki oleh sebuah leksem. Dengan kata lain makna yang sesuai dengan hasil observasi menurut penglihatan, penciuman, pendengaran, perasaan maupun indera lainnya. Dengan demikian, makna denotatif sejatinya serupa dengan makna leksikal. Sedangkan semantik konotatif adalah makna lain yang ditambahkan pada makna denotatif yang berhubungan dengan nilai rasa dari orang yang menggunakan kata tersebut. Konotasi memiliki keunikan tersendiri karena sebuah kata bisa berbeda makna antara seseorang dengan orang lain. Makna konotatif terhubung dengan lingkungan dan waktu di mana ia diucapkan. Contohnya: kata 'anjing' bila diucapkan dalam konteks sebagai umpatan terhadap seseorang bermakna negatif, tetapi bila dikatakan dalam suatu komunitas pecinta binatang makanya positif. Semantik konseptual adalah makna yang dimiliki oleh sebuah leksem terlepas dari konteks atau asosiasi apapun. Makna konseptual sebenarnya sama dengan makna leksikal, denotatif dan makna referensial. Misalnya kata kuda memiliki makna konseptul sejenis binatang berkaki empat yang biasa dikendarai. Semantik asosiatif adalah makna yang dimiliki sebuah kata atau leksem berkenaan dengan adanya hubungan kata itu dengan keadaan di luar bahasa. Makna asosiasi sama dengan perlambangan yang digunakan oleh suatu masyarakat bahasa untuk menyatakan konsep lain, yang mempunyai kemiripan sifat, keadaaan atau ciri-ciri yang ada pada leksem tersebut. Misalnya kata 'kursi' berasosiasi dengan jabatan dan kedudukan, kata 'melati' berasosiasi dengan kesucian[34]. 
Kamus Besar Bahasa Indonesia menyebutkan arti 'kata' adalah unsur bahasa yang diucapkan atau dituliskan yang merupakan perwujudan kesatuan perasaan dan pikiran yang dapat digunakan dalam berbahasa. Sedangkan arti 'istilah' adalah kata atau gabungan kata yang dengan cermat meng-ungkapkan makna konsep, proses, keadaan, atau sifat yang khas dalam bidang tertentu[35]. Pada awalnya, makna yang dimiliki oleh sebuah kata adalah makna leksikal, denotatif atau makna konseptual. Namun, dalam penggunaannya makna kata itu baru menjadi jelas jika kata itu sudah berada di dalam konteks kalimatnya atau konteks situasinya. Istilah mempunyai makna yang pasti, jelas, tidak meragukan, meskipun tanpa konteks kalimat. Oleh karena itu, istilah sering dikatakan bebas konteks, sedangkan kata tidak bebas konteks[36]. Dalam Kamus Besar Bahasa Indonesia 'idiom' bermakna konstruksi yang maknanya tidak sama dengan gabungan makna unsurnya. Sedangkan 'peribahasa' bermakna kelompok kata atau kalimat yang tetap susunannya, biasanya mengiaskan maksud tertentu (dalam peribahasa termasuk juga bidal, ungkapan, perumpamaan)[36]. Semantik idiom adalah makna leksikal yang terbentuk dari beberapa kata. Kata-kata yang disusun dengan kombinasi kata lain dapat pula menghasilkan makna berlainan. Misalnya: 'kambing hitam' bermakna orang yang dituduh menyebabkan bencana atau masalah, 'meja hijau' bermakna pengadilan dan 'membanting tulang' bermakna bekerja keras. Sedangkan semantik peribahasa adalah makna yang hampir mirip dengan makna idiom, akan tetapi terdapat perbedaan, makna peribahasa adalah makna yang masih dapat ditelusuri dari makna unsur-unsurnya karena adanya asosiasi antara makna asli dengan maknanya sebagai peribahasa, sedangkan makna idiom tidak dapat diramalkan. Idiom dan peribahasa terdapat pada semua bahasa yang ada di dunia ini, terutama pada bahasa-bahasa yang penuturnya sudah memiliki kebudayaan yang tinggi. Misalnya, seperti anjing dan kucing yang bermakna dua orang yang tidak pernah akur. Makna ini memiliki asosiasi bahwa binatang yang namanya anjing dan kucing jika bersuara memang selalu berkelahi, tidak pernah damai

\section{SIMPULAN}

Kajian ini menjabarkan bahwa dalam bahasa terdapat struktur yang menjadi bagian dari studi linguistik yang banyak cabangnya. Korelasi antar struktur atau komponen bahasa itu prosesnya memiliki alur sebagai berikut: (1) Bahasa pada mulanya berupa bunyi-bunyi abstrak yang mengacu adanya lambang atau simbol tertentu; (2) Sekumpulan lambang atau simbol merupakan seperangkat sistem yang memiliki tatanan ataupun kaidah tertentu; (3) Sekumpulan lambang atau simbol yang membentuk komponen tata bahasa dan memiliki bentuk dan kaidah itu mengasosiasikan suatu makna tersendiri. Pengkajian lebih detail terkait tahapan mulai dasar hingga akhirnya suatu struktur bahasa menjadi bidang kajian ilmu linguistik; fonologi, morfologi, sintaksis dan semantik. (1) Fonologi adalah bidang keilmuan yang membahas tentang bunyibunyi bahasa dan fungsinya. (2) Morfologi adalah bidang keilmuan linguistik yang membahas tentang seluk-beluk kata dan proses perubahannya. (3) sintaksis adalah bidang keilmuan linguistik yang membahas tentang susunan kata dan kelompok kata yang membentuk frasa, klausa, kalimat maupun wacana. (4) Semantik adalah bidang keilmuan linguistik yang membahas tentang makna ungkapan bahasa atau makna dari hubungan antar kata yang membentuk frasa, klausa, kalimat maupun wacana.

\section{REFERENCES}

[1] Keraf, "Kutipan dan sistem rujukan 1.," 1997.

[2] R. D. Lestari, E. S. Aeni, and L. B. Penelitian, "Penggunaan gaya bahasa perbandingan pada kumpulan cerpen mahasiswa," Semantik, vol. 7, no. 1, pp. 1-11, 2018, doi: 10.22460/semantik.vXiX.XXX.

[3] E. Hutapea, "Indonesia Punya 718 Bahasa Ibu, Jangan Sampai Punah," Kompas, 2020. https://edukasi.kompas.com/read/2020/02/22/21315601/indonesia-punya-718-bahasa- 
ibu-jangan-sampai-punah?page=all (accessed Dec. 18, 2020).

[4] N. W. Sartini, "Bahasa Pergaulan Remaja: Analisis Fonologi Generatif," MOZAIK J. Ilmu Hum., vol. 12, no. 2, pp. 122-132, 2012, [Online]. Available: http://journal.unair.ac.id/download-fullpapers-mozaik9116dae378full.pdf.

[5] Sarwiji, "Semantik Pengantar Kajian Makna," Int. J. Ihya' 'Ulum al-Din, 2011.

[6] L. Suratminto, "Kamus Linguistik," Wacana, J. Humanit. Indones., 2014.

[7] S. Gani and B. Arsyad, "Kajian Teoritis Struktur Internal Bahasa (Fonologi, Morfologi, Sintaksis, dan Semantik)," A'Jamiy J. Bhs. dan Sastra Arab, vol. 07, no. 1, pp. 1-20, 2018, doi: http://dx.doi.org/10.31314/ajamiy.7.1.1-20.2018.

[8] Suryabrata, Metodologi Penelitian. 2014.

[9] Mukhtar, Metode Praktis Penelitian Deskriptif Kualitatif. 2013.

[10] N. Budiana, "Pemerolehan Bahasa Anak Usia 2,5 Tahun Tataran Fonologi - Morfologi dan Sintaksis," J. Ilm. Semant., vol. 1, no. 02, 2020.

[11] D. Hartanto, "Hubungan Personal Mastery Dengan Kepemimpinan Pada Organisasi Barekskrim Polri," JUSTITIA J. Ilmu Huk. dan Hum., vol. 7, no. 4, pp. 856-864, 2020, doi: http://dx.doi.org/10.31604/justitia.v7i4.856-864.

[12] Y. D. A. W. P. Yuliantini, "Semiotika Dalam Novel Rembulan Tenggelam Di Wajahmu Karya Tere Liye," J. Literasi, vol. 1, no. 2, pp. 65-72, 2017, doi: http://dx.doi.org/10.25157/literasi.v1i2.785.

[13] J. Danandjaja, "Metode Penelitian Kepustakaan," Antropol. Indones., 2014, doi: 10.7454/ai.v0i52.3318.

[14] M. Muslich, "Fonologi Bahasa Indonesia: Tinjauan Deskriptif Sistem Bunyi Bahasa Indonesia," Jakarta PT. Bumi Aksara, 2008.

[15] K. Koderi, "PENERAPAN MODEL PEMBELAJARAN BAHASA ARAB BERBASIS SAVI (Somatis, Auditori, Visual, Intelektual) DALAM MENINGKATKAN HASIL BELAJAR PADA PESERTA DIDIK," J. Al Bayan J. Jur. Pendidik. Bhs. Arab, vol. 10, no. 01, 2018, doi: 10.24042/albayan.v10i01.2596.

[16] M. S. Effendi, "Linguistik sebagai Ilmu Bahasa,” J. Perspekt. Pendidik., 2012.

[17] S. Pujiono, "BUNYI BAHASA," Universitas Negeri Yogyakarta. .

[18] F. Lafamane, "FONOLOGI (Sejarah Fonologi, Fonetik, Fonemik)," osfpreprints, 2020, doi: 10.31219/osf.io/snmfh.

[19] J. Badrudin, M. N. Latif, and A. H. Shahidi, "Fonologi Bahasa Kantuk: Kekerabatan dan keeratannya dengan Bahasa Iban dan dialek Melayu Semenanjung," Geogr. Online, vol. 1, no. 1, pp. 94-100, 2014.

[20] J. Pesona, D. Kurniawati, F. I. Budaya, and U. Padjadjaran, "Inovasi Leksikal Bahasa Jawa Di Kabupaten Pringsewu Lampung," J. Pesona, vol. 3, no. 1, 2017, doi: https://doi.org/10.26638/jp.303.2080.

[21] I. S. K. Ramsi, "Infleksi Dalam Bahasa Kulisusu," Jusrnal Bastra, vol. 1, pp. 1-8, 2017, doi: http://dx.doi.org/10.36709/jb.v1i4.2307.

[22] A. M. M. Alwi, Soenjono Dardjowidjojo, Hans Lapoliwa, "Tata Bahasa Baku Bahasa Indonesia," Dep. Pendidik. dan Kebud. Republik Indones., 1998.

[23] F. Ramadhanti, Y. Wibisono, and R. A. Sukamto, "Analisis Morfologi untuk Menangani Out-of-Vocabulary Words pada Part-of-Speech Tagger Bahasa Indonesia Menggunakan Hidden Markov Model," J. Linguist. Komputasional, vol. 2, no. 1, p. 6, 2019, doi: 10.26418/jlk.v2i1.13.

[24] S. Nafinuddin, "Sintaksis (Komponen dan Struktur)," osfpreprints, 2020, doi: 10.31219/osf.io/a2juk.

[25] S. Santoso, "Hubungan Penguasaan Sintaksis dan Penalaran Dengan Kemampuan Menulis Paragraf Eksposisi (Penelitian Korelasi di STKIP Kusuma Negara Jakarta)," Syntax Lit. J. Ilm. Indones., vol. 5, no. 3, 2020, doi: http://dx.doi.org/10.36418/syntax-literate.v5i3.984.

[26] Shaharina Mokhtar and Shahidi A.H., "Analisis Frekuensi Asas (F0) Bunyi Vokal Bahasa Melayu: Pencerakinan Berdasarkan Fonetik Akustik," J. Bhs., 2014.

[27] G. Thabroni, "Pengertian Kata, Frasa, Klasusa dan Satuan Gramatik Lainnya," Serupa.id, 
2020. https://serupa.id/pengertian-kata-frasa-klausa-dan-satuan-gramatik-lainnya/ (accessed Dec. 20, 2020).

[28] A. Admin, "Pengertian Subject, Predikat, dan Object \& Contohnya," ruangseni, 2020. https://ruangseni.com/pengertian-subjek-predikat-dan-objek-contohnya/ (accessed Dec. 20, 2020).

[29] E. Subroto, Pengantar Studi Semantik dan Pragmatik. 2011.

[30] S. Sumarti, I. Suniarti, and E. S. Agustina, "Lintas BUdaya (Interkultural) Dalam Pembelajaran Berbicara Bagi Peserta BIPA Darmasiswa Di Universitas Lampung," Konf. Int. Pengajaran Bhs. Indones. bagi Penutur Asing XI, pp. 357-370, 2019.

[31] M. I. Sukardi, S. Sumarlam, and S. Marmanto, "Penyimpangan Makna Dengan Homonimi Dalam Wacana Meme (Kajian Semantik)," Ling. J. Ilmu Bhs. dan Sastra, vol. 13, no. 1, p. 23, 2018, doi: 10.18860/ling.v13i1.4513.

[32] E. Suryaningrat, "Pengertian, Sejarah dan Ruang Lingkup Kajian Semantik (Ilmu Dalalah)," At-Ta'lim, 2012. .

[33] E. Setiawan, "mobil," kata dasar mobil, 2019. https://kbbi.web.id/mobil (accessed Dec. 20, 2020).

[34] H. Halimatussakdiah and N. Nurmayani, "Peningkatan Kemampuan Berbicara Dalam Matakuliah Keterampilan Berbahasa Indonesia Pada Mahasiswa Prodi PGSD FIP UNIMED," J. Guru Kita, vol. 2, no. 2, 2018, doi: https://doi.org/10.24114/jgk.v2i2.9446.

[35] E. Setiawan, "Kata," kbbi, 2019. https://kbbi.web.id/kata (accessed Dec. 12, 2020).

[36] E. Setiawan, "idiom," kbbi, 2019. https://kbbi.web.id/idiom (accessed Dec. 20, 2020). 